Prepared in cooperation with

Ohio Environmental Protection Agency, U.S. Fish and Wildlife Service, Contaminants Program, Pennsylvania Department of Environmental Protection, and West Virginia University

\title{
Assessment of the Fish Tumor Beneficial Use Impairment in Brown Bullhead (Ameiurus nebulosus) at Selected Great Lakes Areas of Concern
}

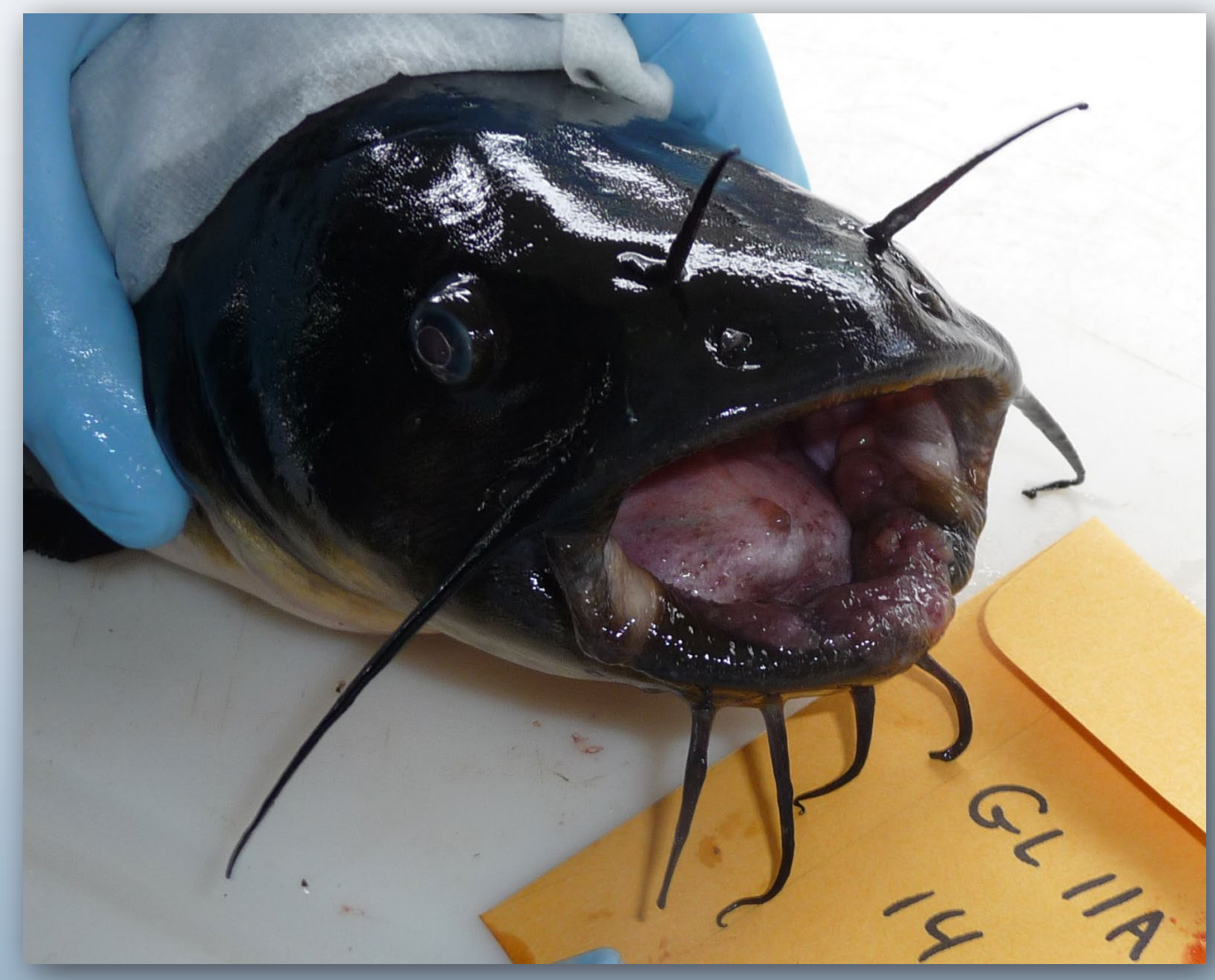

Open-File Report 2014-1105 
Cover. Photograph of a brown bullhead (Ameiurus nebulosis) with lip lesion collected in the Niagara River. 


\section{Assessment of the Fish Tumor Beneficial Use Impairment in Brown Bullhead (Ameiurus nebulosus) at Selected Great Lakes Areas of Concern}

By Vicki S. Blazer, Patricia M. Mazik, Luke R. Iwanowicz, Ryan P. Braham, Cassidy M. Hahn, Heather L. Walsh, and Adam J. Sperry

Prepared in Cooperation with

Ohio Environmental Protection Agency, U.S. Fish and Wildlife Service, Contaminants Program, Pennsylvania Department of Environmental Protection, and West Virginia University

Open-File Report 2014-1105 


\title{
U.S. Department of the Interior SALLY JEWELL, Secretary
}

\section{U.S. Geological Survey Suzette M. Kimball, Acting Director}

\author{
U.S. Geological Survey, Reston, Virginia: 2014
}

For more information on the USGS - the Federal source for science about the Earth, its natural and living resources, natural hazards, and the environment, visit http://WWW.usgs.gov or call 1-888-ASK-USGS.

For an overview of USGS information products, including maps, imagery, and publications, visit http://WwW.usgs.gov/pubprod

To order this and other USGS information products, visit http://store.usgs.gov

Any use of trade, firm, or product names is for descriptive purposes only and does not imply endorsement by the U.S. Government.

Although this information product, for the most part, is in the public domain, it also may contain copyrighted materials as noted in the text. Permission to reproduce copyrighted items must be secured from the copyright owner.

Suggested citation:

Blazer, V.S., Mazik, P.M., Iwanowicz, L.R., Braham, R.P., Hahn, C.M., Walsh H.L., and Sperry, A.J., 2014, Assessment of the fish tumor beneficial use impairment in brown bullhead (Ameiurus nebulosus) at selected Great Lakes Areas of Concern: U.S. Geolological Survey Open-File Report 2014-1105, 17 p., http://dx.doi.org/10.3133/ofr20141105.

ISSN 2331-1258 (online) 


\section{Acknowledgments}

This project was funded by the Great Lakes Restoration Initiative through grants to Ohio Environment Protection Agency, Pennsylvania Department of Environmental Protection, and the Fish and Wildlife Service Contaminants program, and by the U.S. Geological Survey's Ecosystems (Fisheries), Environmental Health (Contaminant Biology) and Cooperative Fish and Wildlife Research Unit programs. The authors thank the numerous people responsible for field logistic arrangements and fish collections, especially Jo Ann Banda, Daniel Gefell, and Jeremy Moore with the U.S. Fish and Wildlife Service; James Grazio with Pennsylvania Department of Environmental Protection; Sean Rafferty with Pennsylvania Sea Grant; and Travis Smith with the Midwest Biodiversity Institute. We thank U.S. Geological Survey histology technicians Darlene Bowling and Kathy Spring for their assistance and Dr. John Fournie, U.S. Environmental Protection Agency, for a critical review of the manuscript. 


\section{Contents}

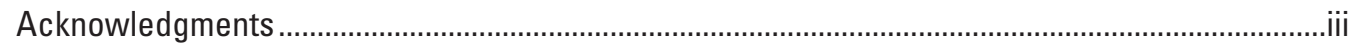

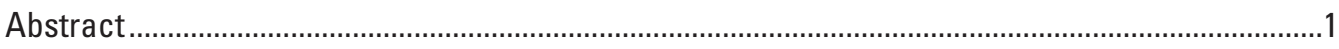

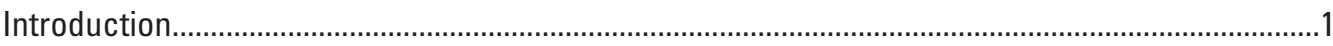

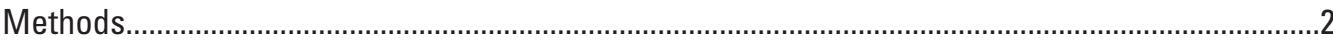

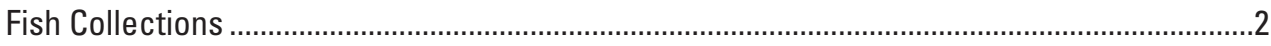

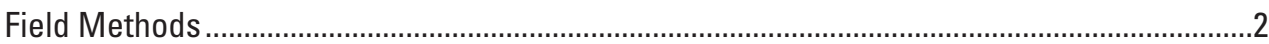

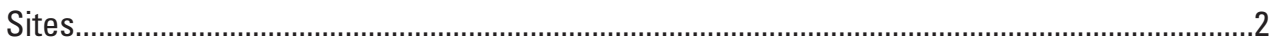

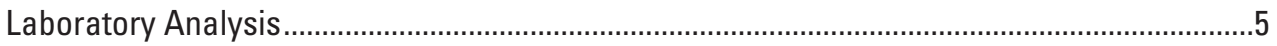

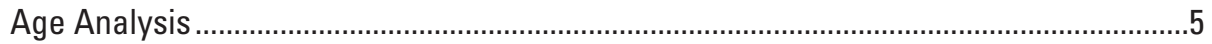

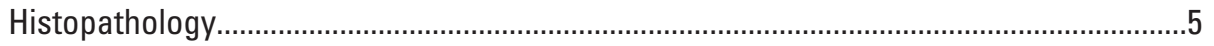

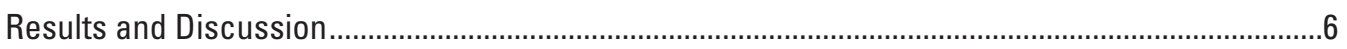

Visible External Lesions .........................................................................................................

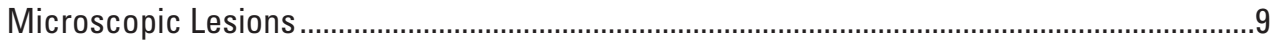

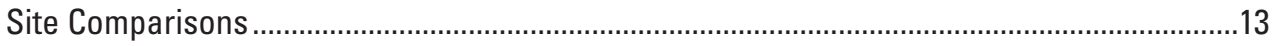

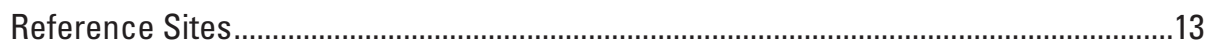

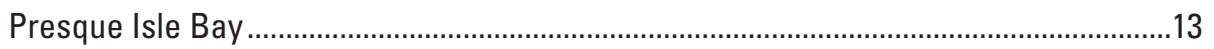

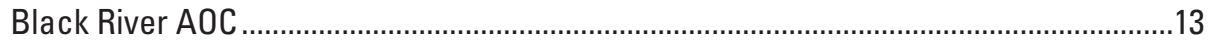

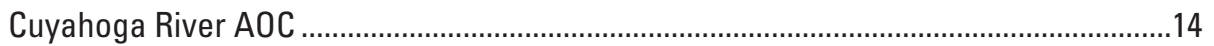

Maumee River AOC ................................................................................................. 14

Rochester Embayment AOC .......................................................................................... 14

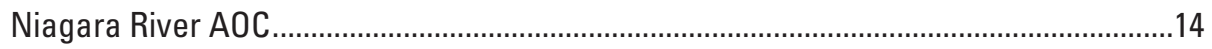

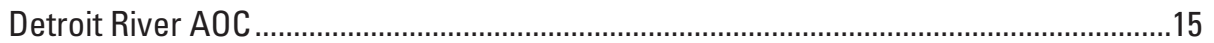

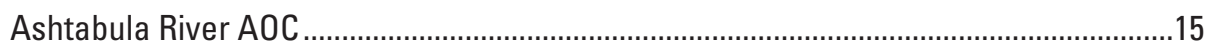

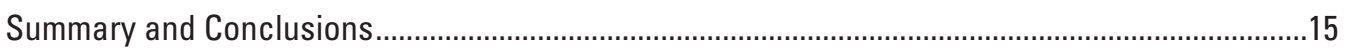

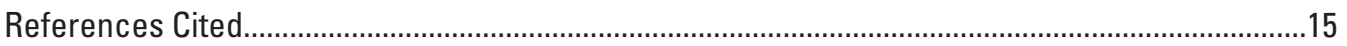

Appendix 1. Morphometric Data, Visible and Microscopic Abnormalities....................................17 


\section{Figures}

1. Map showing sampling locations for brown bullhead tumor surveys in the Great Lakes Basin, 2011-2013

2. Photographs showing grossly visible lesions on the external surfaces of brown bullhead: $A$, melanistic areas on the lateral surface, $B$, raised areas on the barbels, $C$, raised areas on the lips and mouth, $D$, pale raised area on the body surface, $E$, small raised area on the body surface, and $F$, raised black lesion on the fin...

3. Photographs showing microscopic appearance of $A$, normal and $B$, melanistic areas of skin observed on the body surface of brown bullhead

4. Photographs showing microscopic appearance of raised lesions observed on brown bullhead: $A$, papilloma characterized by papillary folds of proliferating epithelial cells that do not penetrate through the basement membrane, $B$, section of a squamous cell carcinoma of the body surface with neoplastic epithelial cells invading through the basement membrane into the underlying dermis, $C$, section of an osteoma with anastosmosing irregular trabeculae of proliferating bone, $D$, osteosarcoma characterized by thin trabeculae of neoplastic bone within a matrix of fibrous tissue .

5. Photographs showing microscopic appearance of proliferative liver lesions:

$A$, vacuolated cell focus comprised of hepatocytes with large clear cytoplasmic vacuoles and no distinct border separating it from surrounding hepatocytes, $B$, hepatic adenoma causing compression (arrows) of surrounding tissue, $C$, bile duct hyperplasia is characterized by increased profiles of normal bile ducts, often in multiple areas throughout the tissue and $D$, cholangiocarcinoma comprised of bile ducts abnormal in size and morphology and invading into the surrounding tissue.

\section{Tables}

1. Sites, sampling dates, and sample sizes for brown bullhead collections at selected Great Lakes Basin Areas of Concern and reference sites, 2011-2013.............................6

2. Percentage of brown bullhead with lip, body surface, and barbel abnormalities ...........8

3. Percentage of brown bullhead with external and liver neoplasms and putative preneoplastic liver lesions 


\section{Conversion Factors}

\begin{tabular}{|c|c|c|}
\hline Multiply & By & To obtain \\
\hline \multicolumn{3}{|c|}{ Length } \\
\hline inch (in.) & 2.54 & centimeter $(\mathrm{cm})$ \\
\hline inch (in.) & 25.4 & millimeter $(\mathrm{mm})$ \\
\hline foot (ft) & 0.3048 & meter $(\mathrm{m})$ \\
\hline mile (mi) & 1.609 & kilometer $(\mathrm{km})$ \\
\hline yard (yd) & 0.9144 & meter $(\mathrm{m})$ \\
\hline \multicolumn{3}{|c|}{ Volume } \\
\hline ounce, fluid (fl. oz) & 0.02957 & liter $(\mathrm{L})$ \\
\hline $\operatorname{pint}(\mathrm{pt})$ & 0.4732 & liter $(\mathrm{L})$ \\
\hline quart (qt) & 0.9464 & liter $(\mathrm{L})$ \\
\hline gallon (gal) & 3.785 & liter (L) \\
\hline \multicolumn{3}{|c|}{ Mass } \\
\hline ounce, avoirdupois (oz) & 28.35 & gram $(g)$ \\
\hline pound, avoirdupois (lb) & 0.4536 & kilogram (kg) \\
\hline
\end{tabular}

\begin{tabular}{lll}
\multicolumn{1}{c}{ SI to Inch/Pound } & \multicolumn{1}{c}{ Multiply } & \multicolumn{1}{c}{ To obtain } \\
\hline \multicolumn{1}{c}{ Length } & \\
\hline centimeter (cm) & 0.3937 & inch (in.) \\
millimeter (mm) & 0.03937 & inch (in.) \\
meter (m) & 3.281 & foot (ft) \\
kilometer (km) & 0.6214 & mile (mi) \\
meter (m) & 1.094 & yard (yd) \\
\hline & \multicolumn{1}{c}{ Volume } & \\
liter (L) & 33.82 & ounce, fluid (fl. oz) \\
liter (L) & 2.113 & pint (pt) \\
liter (L) & 1.057 & quart (qt) \\
liter (L) & 0.2642 & gallon (gal) \\
\hline & \multicolumn{1}{c}{ Mass } & \\
\hline gram (g) & 0.03527 & ounce, avoirdupois (oz) \\
kilogram (kg) & 2.205 & pound avoirdupois (lb) \\
\hline
\end{tabular}

Temperature in degrees Celsius $\left({ }^{\circ} \mathrm{C}\right)$ may be converted to degrees Fahrenheit $\left({ }^{\circ} \mathrm{F}\right)$ as follows:

${ }^{\circ} \mathrm{F}=\left(1.8 x^{\circ} \mathrm{C}\right)+32$

Temperature in degrees Fahrenheit $\left({ }^{\circ} \mathrm{F}\right)$ may be converted to degrees Celsius $\left({ }^{\circ} \mathrm{C}\right)$ as follows:

${ }^{\circ} \mathrm{C}=\left({ }^{\circ} \mathrm{F}-32\right) / 1.8$ 


\title{
Assessment of the Fish Tumor Beneficial Use Impairment in Brown Bullhead (Ameiurus nebulosus) at Selected Great Lakes Areas of Concern
}

\author{
By Vicki S. Blazer ${ }^{1}$, Patricia M. Mazik', Luke R. Iwanowicz', Ryan P. Braham², Cassidy M. Hahn², \\ Heather L. Walsh', and Adam J. Sperry²
}

\section{Abstract}

A total of 878 adult brown bullhead were collected at 11 sites within the Lake Erie and Lake Ontario drainages from 2011 to 2013. The sites included seven Areas of Concern (AOC; 670 individuals), one delisted AOC (50 individuals) and three nonAOC sites (158 individuals) used as reference sites. These fish were used to assess the "fish tumor or other deformities" beneficial use impairment. Fish were anesthetized, weighed, measured and any external abnormalities documented and removed. Abnormal orocutaneous and barbel tissue, as well as five to eight pieces of liver, were preserved for histopathological analyses. Otoliths were removed and used for age analyses. Visible external abnormalities included reddened (raised or eroded), melanistic areas and raised growths on lips, body surface, fins, and barbels. Microscopically, these raised growths included papilloma, squamous cell carcinoma, osteoma, and osteosarcoma. Proliferative lesions of the liver included bile duct hyperplasia, foci of cellular alteration, bile duct (cholangioma, cholangiocarcinoma) and hepatocellular (adenoma, hepatic cell carcinoma) neoplasia. The two reference sites (Long Point Inner Bay, Conneaut Creek) at which 30 or more bullhead were collected had a skin tumor prevalence of 10 percent $(\%)$ or less and liver tumor prevalence of $4 \%$ or less. Presque Isle Bay, recently delisted, had a similar liver tumor prevalence (4\%) and slightly higher prevalence (12\%) of skin tumors. The prevalence of skin neoplasms was $15 \%$ or less at sites in the Black River, Cuyahoga River, and Maumee AOCs, while more than 20\% of the bullheads from the Rochester Embayment, Niagara River, Detroit River, and Ashtabula River AOCs had skin tumors. The prevalence of liver tumors was greater than 4\% at all AOC sites except the Old Channel site at the Cuyahoga River AOC, Wolf Creek within the Maumee AOC, and the upper and lower sites within the Niagara River AOC.

\section{Introduction}

Areas of Concern (AOCs) were defined by the United States and Canada Great Lakes Water Quality Agreement, Annex 2 of the 1987 Protocol as "geographic areas that fail to meet the general or specific objectives of the agreement where such failure has caused or is likely to cause impairment of beneficial use of the area's ability to support aquatic life." Fourteen beneficial use impairments (BUIs) were identified by the International Joint Commission (IJC), one of which is the fish tumors or other deformities (IJC 1991). The Great Lakes Water Quality Agreement directs the Canadian and United States governments, together with provincial or state agencies to develop and implement remedial action plans (RAP), directed at restoring and protecting the beneficial uses and delisting the AOC. Initially, the focus at AOCs was on legacy contaminants such as metals, polyaromatic hydrocarbons (PAHs) and polycyclic aromatic biphenyls (PCBs). More recently, it has been recognized that chemicals of emerging concern (CEC), including substances such as biogenic hormones (human and animal), brominated flame retardants, pharmaceuticals, personal care products, plasticizers, current use pesticides, and detergents may also be contributing to impaired health of Great Lakes fish and wildlife (IJC, 2009; Klaper and Welch, 2011; Klečka and others, 2010; Blair and others, 2013). The 2012 Protocol reaffirms the commitment "to provide a vital framework for binational consultation and cooperative action to restore, protect and enhance the water quality of the Great Lakes to promote the ecological health of the Great Lakes basin." This Protocol defines an AOC as a geographic area designated by the Parties where significant impairment of beneficial uses has

${ }^{1}$ U.S. Geological Survey

${ }^{2}$ West Virginia University 
occurred as a result of human activities at the local level. A BUI is defined as a reduction in the chemical, physical, or biological integrity of the waters of the Great Lakes sufficient to cause one of the 14 identified beneficial uses (http://www.ijc.org/en_ _ Great_Lakes_Water_Quality).

The "fish tumor or other deformities" BUI is defined as occurring "when the incidence rates of fish tumors or other deformities exceed rates at unimpacted control sites or when survey data confirm the presence of neoplastic or preneoplastic liver tumors in bullheads or suckers" (IJC, 1989). Both brown bullhead (Ameiurus nebulosus) and white sucker (Catostomus commersonii) have been used extensively in the Great Lakes watershed as indicator species, particularly in relation to skin and liver tumors (Baumann and others, 1996; Blazer and others, 2009a,b; Hayes and others, 1990; Premdas and others, 1995; Rafferty and others, 2009; Smith and others, 1989). Unfortunately, the IJC did not define or identify "unimpacted control sites" or define the hepatic lesions to be considered preneoplastic. Hence, historically there has been a lack of consistency in addressing this BUI (Rafferty and others, 2009). In an attempt to develop standardized methods the Pennsylvania Department of Environmental Protection (PADEP), Pennsylvania Sea Grant and the Presque Isle Bay Public Advisory Committee sponsored a series of conferences to obtain expert advice and develop recommendations. The recommendations made included the need for appropriate documentation of visible lesions (Rafferty and Grazio, 2006), collection of tissue from visible lesions for verification of neoplasia, diagnostic criteria for the skin and liver microscopic lesions (Blazer and others, 2006; 2007), evaluation of reference sites and analyses of covariates such as age and sex (Blazer and others, 2009a,b; Rafferty and others, 2009).

The Great Lakes Restoration Initiative, instituted in 2010, targets certain priorities that include evaluating and monitoring progress at AOCs. This study was conducted by the U.S. Geological Survey in cooperation with Ohio Environmental Protection Agency; U.S. Fish and Wildlife Service, Contaminants Program; Pennsylvania Department of Environmental Protection; and West Virginia University to address those priorities. The purpose of this report is to present data collected at seven current AOCs, one delisted AOC and three reference sites, directed at evaluating and monitoring the fish tumor BUI.

\section{Methods}

\section{Fish Collections}

From spring 2011 through spring 2013, 878 brown bullhead were collected at multiple sites within eight AOCs and at three reference sites (fig. 1, table 1). Fish were collected by Fish and Wildlife Service personnel using fyke nets and boat electrofishing techniques in the Detroit River, Ashtabula River, Rochester Embayment, and Niagara River AOCs and Conneaut Creek (2011 collections). Personnel from Pennsylvania Sea Grant and Department of Environmental Protection collected brown bullheads from Presque Isle Bay and Long Point Inner Bay. U.S. Geological Survey and West Virginia University personnel necropsied the fish on site and collected samples for histopathology at these locations. Personnel from the Midwest Biodiversity Institute, Columbus, Ohio collected brown bullhead using boat electroshocking and fyke nets at the Black River, Cuyahoga River, and Maumee AOCs, as well as the Huron River and in 2013, Conneaut Creek. They necropsied the fish on site, collected tissues and sent the fixed tissues to the Leetown Science Center histopathology laboratory.

\section{Field Methods}

Attempts were made to collect 20 to 50 mature ( $>250$ millimeter $[\mathrm{mm}]$ total length) brown bullhead at each site. Fish were anesthetized with MS-222 (Tricane Methanesulfonate, Argent Chemical Laboratories, Redmond, Washington), weighed to the nearest gram (gm) and measured (total length) to the nearest $\mathrm{mm}$. A comprehensive necropsy-based assessment was completed on each fish collected and all visible abnormalities (Smith and others, 2002; Rafferty and Grazio, 2006) documented. Lip and body surface lesions included reddened (raised and non-raised) or eroded areas, non-raised melanistic areas, and raised papillomatous lesions. Barbel abnormalities included small raised areas, missing, shortened, and deformed barbels (fig. 2). Five to seven pieces of liver and any external abnormalities were placed in Z-fix ${ }^{\mathrm{TM}}$ fixative (Anatech Ltd., Battle Creek, Michigan). The lapillus otoliths were removed and placed in a labeled coin envelope for subsequent processing and age analysis.

\section{Sites}

The Black River AOC is located in north-central Ohio and is impacted by high residential growth and intensive agriculture. Historically, the AOC included only the lower mainstem of the Black River due to high sediment contamination by industrial discharges. Remedial dredging and impacts from point sources have been significantly reduced in this area of the river. The RAP committee expanded the AOC to include the entire watershed. Liver and skin neoplasms in brown bullhead have been monitored 


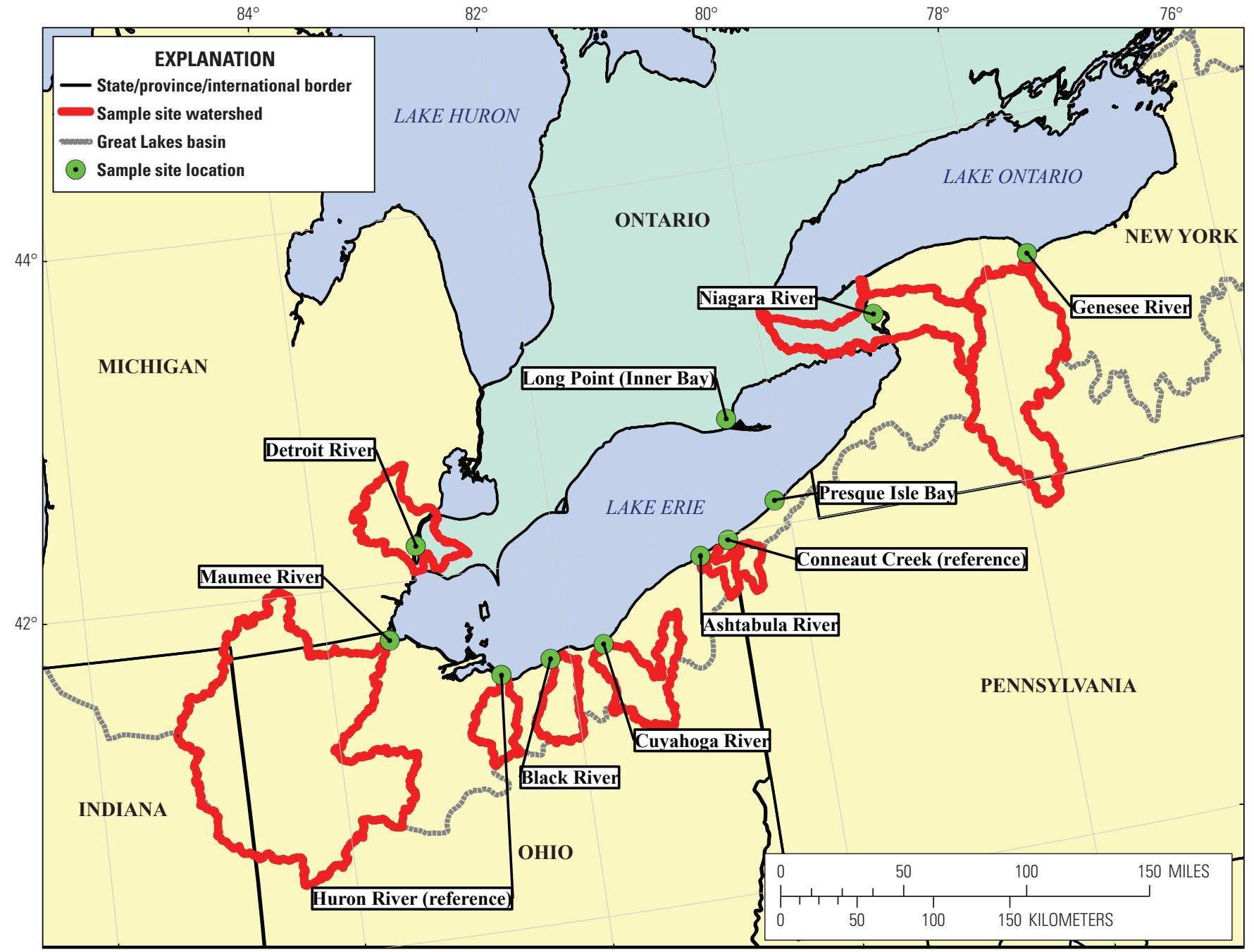

Base from U.S. Geological Survey

1:1,500,000-scale digital data

Figure 1. Sampling locations for brown bullhead tumor surveys in the Great Lakes Basin, 2011-2013. 
in the Black River since the 1980s. The closing of a coking plant and remedial dredging of contaminanted sediments resulted in a decreased prevalence of liver tumors (reviewed by Baumann and Harshbarger, 1998; Blazer and others, 2009b). Skin tumors have remained elevated (Arcand-Hoy and Metcalfe, 1999; Blazer and others, 2009a). Since 2004 the fish tumor BUI has been listed as impaired but in the recovery phase. Brown bullhead were collected in both the upper (between river miles 2.5 and 5.0) and lower (between the mouth and river mile 2.5) Black River.

The Cuyahoga River AOC encompasses the lower river section from Suffield, Portage County to the mouth at Lake Erie at Cleveland (approximately 113 miles [mi]) and the Lake Erie shoreline from Clifton Park to Wildwood Park (approximately $12 \mathrm{mi}$ ). It flows through much of the industrial and urban area of northeast Ohio and contaminant sources include various industrial and municipal discharges. Previous tumor surveys have indicated a high prevalence of skin and liver tumors (Smith and others, 1994; Blazer and others, 2009a,b). Despite the high skin (75\%) and liver (19\%) tumor prevalence at the upstream site in a survey conducted in 1999 (Blazer and others, 2009a,b), Ohio EPA and the Cuyahoga River RAP committee has proposed to delist this BUI in the navigational channel of the Cuyahoga River (http://www.crcpo.org/Delisting\%20Request\%2041609. $p d f)$. Brown bullhead were collected in the Old Channel and the New Channel of the Cuyahoga River (Clevelend Harbor) and Euclid Creek.

The Maumee AOC contains 12 watersheds. In 2001, when an incremental approach to delisting Great Lakes AOC was adopted, 10 of the 12 watersheds were listed as impaired for the fish tumor BUI (http://www.epa.gov/glnpo/aoc/ maumee.html). Agricultural runoff, old dumps and industrial sites, combined sewer overflows, and disposal of dredged material are identified as contributing contaminants within this AOC. To our knowledge the fish tumor prevalence has only been assessed previously in the lower portion of the Maumee River, and the prevalence of both skin and liver neoplasms was low, less than 4\% (Blazer and others, 2009a,b). Brown bullhead were collected in six of the 10 impaired watersheds: Swan Creek/Maumee River, Ottawa River, Otter Creek, Turtle Creek, Wolf Creek, and the Toussaint River.

The Rochester Embayment AOC is on southern shore of Lake Ontario. The embayment is delineated by a straight line between Bogus Point in Parma and Nine Mile Point in Webster, NY, and includes the the Genesee River from the mouth to the Lower Falls. The entire Genesee Basin drains into the Rochester Embayment. The fish tumor BUI was considered undetermined in the Stage 1 RAP. However, in 2009 all undetermined BUIs were listed as impaired and hence, in the Stage II RAP the fish tumor BUI was included. A study of brown bullhead from the Braddock Bay area of the AOC was conducted in 2010, and no tumors were observed (http://www.dec.ny.gov/docs/water_pdf/rochaocrap2fnl.pdf accessed February 3, 2014). The sites assessed in the current study were the Genesee River, Irondequoit Bay, and Long Pond. To our knowledge fish tumor surveys have not been conducted previously at these sites.

The Niagara River connects Lake Erie and Lake Ontario. The United States portion of the AOC includes approximately $7.5 \mathrm{mi}$ (12.1 kilometers [km]) of industrially developed waterways (Buffalo Outer Harbor, Black Rock Canal) along the eastern shore of Lake Erie, the uppermost reach of the Niagara River and approximately $32 \mathrm{mi}(51.5 \mathrm{~km})$ of river. Studies in the $1980 \mathrm{~s}$ demonstrated a high prevalence of liver tumors (24\%) in the upper river and skin or barbel abnormalities at a higher rate than reference sites (Hirethota 1992). The tumor BUI was one of five BUI listed as impaired in 1994 and in the January 2012 RAP Addendum (http://www.dec.ny.gov/docs/water_pdf/instage2addFinal.pdf). The current study divided the river into upper, middle, and lower zones for fish collections. The upper zone was separated into two sites, the developed shoreline (Buffalo Outer Harbor and Black Rock Canal) and undeveloped shoreline (Strawberry Island and East River Marsh). The middle zone was also divided into two sites, the northeast end of Grand Island and Love Canal. The lower zone included the portion of the river below Niagara Falls to the mouth.

The Ashtabula River is located in northeastern Ohio, and decades of industrial metal fabrication, chemical production and mismanagement of waste disposal led to Fields Brook, a tributary of Ashtabula, being designated a Superfund site and the lower two mi $(3.2 \mathrm{~km})$ of the river designated as an AOC. Fish health assessments prior to remediation demonstrated reduced health of brown bullhead, including an increased prevalence of skin and liver tumors, when compared to a reference site (Blazer and others, 2009a,b; Iwanowicz and others, 2012). Remedial actions have occurred, and the current collections within the AOC assist in assessing the efficacy of these actions.

The Detroit River is a 31.7-mi $(51-\mathrm{km})$ channel connecting Lake St. Clair to Lake Erie and is a binational (United States and Canada) AOC that drains approximately 700 square mi $(1,813 \mathrm{sq} \mathrm{km})$ of land within Michigan and Ontario and includes the "sewershed" of the city of Detroit. The Detroit River is a major navigational channel and discharges from combined sewer overflows, municipal, and industrial sources contribute contaminants. Brown bullhead tumor surveys have been conducted in the lower Detroit River since 1985 (Maccubbin and Ersing, 1991; Blazer and others, 2009a,b). Historically, tumor prevalence varied within the Detroit River with the highest prevalence noted in brown bullhead collected from the Trenton Channel (between the mainland of Michigan and Grosse Isle). Sediment contaminant concentrations were also highest in this area (Leadley and others, 1998). The fish tumor BUI remained in the RAP update of 2008 (http://www.epa.gov/grreatlakes/aoc/detroit/pdfs/2008_Detroit_ River_RAP.pdf). Brown bullhead were collected from the Trenton Channel area. 
Presque Isle Bay is a natural embayment on the southern shore of Lake Erie. It was listed as an AOC in 1991 due to contamination from industrial discharges and domestic wastewater. Only two BUIs, the fish tumor and restrictions on dredging, were identified through the RAP process. In 2003 the fish tumor BUI was listed as in recovery, and in 2013 it was delisted despite a liver tumor prevalence greater than $10 \%$ (Blazer and others, 2009b) and a skin tumor prevalence greater than $30 \%$ (Blazer and others, 2009a) documented in surveys conducted in 2004 and 2007.

Reference sites in the current study included Conneaut Creek, the Huron River, and Long Point Inner Bay. The Huron River is a $14.9 \mathrm{mi}(24 \mathrm{~km})$ river in north-central Ohio, entering Lake Erie at the city of Huron, between Toledo and Cleveland. Land use in the watershed is primarily agricultural, but rapid development has increased wastewater discharges, industrial development and surface runoff (Ohio EPA 2005). It has previously been shown to have a low ( $<4.0 \%)$ liver tumor prevalence, although external tumors ranged from 14 to $23 \%$ in previous studies (Smith and others, 1994; Blazer and others, 2009a,b). Conneaut Creek is a tributary of Lake Erie in northwestern Pennsylvania and northeastern Ohio. It has previously been used as a reference site for comparison with the nearby Ashtabula River, having a more diverse fish community, higher biomass, and brown bullhead had lower whole body contaminant burdens of PCBs and organochlorines when compared to the Ashtabula River (Iwanowicz and others 2012). Long Point Inner Bay is a shallow bay on the northern shore (Ontario) of Lake Erie. The major tributary, Big Creek, drains a primarily agricultural watershed (Knapton and Petrie, 1999). This site has been used as a reference site for the Presque Isle Bay studies, and prevalences of skin tumors between 3 and $11 \%$ and liver tumors between 0 and $3 \%$ were observed in earlier surveys (Blazer and others, 2009a,b).

\section{Laboratory Analysis}

\section{Age Analysis}

Lapillus otoliths are prepared by methods modified from Koch and Quist (2007). Whole lapillus otoliths are prepared using a multiple-stage process. First, plastic 2.0 milliliter $(\mathrm{mL})$ flat-top microcentrifuge tube (Fisher Scientific, Pittsburgh, Pennsylvania) caps are filled with modeling clay and the tapered ends removed to create a cylinder. Single lapilli are placed into the clay such that the "thumb" of the otoliths is embedded into the clay. The vial is filled using the Epoxicure ${ }^{\circledR}$ brand of resin and hardener (Buehler Inc., Lake Bluff, Illinois) and allowed to harden. The plastic case is then removed and the otoliths sectioned at approximately $0.64 \mathrm{~mm}$ thickness using an Isomet low speed saw (Buehler Inc. Lake Bluff, Ill.). Sections are read under transmitted light using a stereoscope by two readers. All age data were collected in a "double blind" study, meaning that two individuals read each otolith, and readers' age estimates were independent of biological data.

\section{Histopathology}

Fixed tissue samples were trimmed, placed in cassettes, processed through a series of alcohols and embedded into paraffin. Blocks were sectioned at 5 micrometers $(\mu \mathrm{m})$ and stained with hematoxylin and eosin (Luna, 1992). Slides were examined for any abnormalities as previously described (Blazer and others, 2006, 2007; Boorman and others, 1997; Wolf and Wolfe, 2005). All histopathology slides were read by two investigators (Blazer and Walsh) for quality control. A subset were examined by a third pathologist. 


\section{Results and Discussion}

A number of confounding factors should be recognized when evaluating the data obtained. The first is sample size. There is no universally accepted sample size for the determination of tumor prevalence within a fish population. Rafferty and Grazio (2006) indicate a minimum of 30-50 brown bullhead be randomly selected for histopathology from each sampling location, recognizing that larger subsamples will increase statistical power. Not all collections obtained a minimum of 30 individuals (table 1). The second factor is age. Numerous studies have demonstrated an age effect on both skin and liver tumor prevalence (Baumann and others, 1990; Pinkney and others, 2004; Blazer and others, 2009a,b). For this reason it is suggested fish 3 years of age (250 mm in length) and greater be used in tumor studies (Baumann, 1992; Rafferty and Grazio, 2006). The mean age and length of bullhead collected in this study varied among sites. For most sites the mean age was in the 5-7 year range. A younger mean age was observed in the Maumee River, Wolf Creek, Otter Creek, lower Niagara River site, and the Huron River. A slightly older mean age was noted in fish collected from the Rochester Embayment sites (table 1). Samples at a number of sites (appendix 1)

Table 1. Sites, sampling dates, and sample sizes for brown bullhead collections at selected Great Lakes Basin Areas of Concern (AOC), and reference sites, 2011-2013.

[mm, millimeters; yr, year]

\begin{tabular}{|c|c|c|c|c|}
\hline Areas of Concern & Sampling date & Sample size & Mean age (yr) & Length (mm) \\
\hline $\begin{array}{l}\text { Black River } \\
\text { Upper Black } \\
\text { Lower Black }\end{array}$ & $\begin{array}{l}05 / 21 / 2013 \\
08 / 15 / 2012\end{array}$ & $\begin{array}{l}40 \\
30\end{array}$ & $\begin{array}{l}6.3 \pm 0.2 \\
5.2 \pm 0.4\end{array}$ & $\begin{array}{l}354.9 \pm 3.6 \\
316.9 \pm 7.7\end{array}$ \\
\hline $\begin{array}{l}\text { Cuyahoga River } \\
\text { New Channel } \\
\text { Old Channel } \\
\text { Euclid Creek }\end{array}$ & $\begin{array}{l}09 / 07 / 2012 \\
09 / 06 / 2012 \\
05 / 08 / 2013\end{array}$ & $\begin{array}{l}24 \\
27 \\
40\end{array}$ & $\begin{array}{l}5.1 \pm 0.4 \\
5.1 \pm 0.4 \\
5.9 \pm 0.3\end{array}$ & $\begin{array}{l}283.5 \pm 7.0 \\
303.4 \pm 7.3 \\
324.7 \pm 7.0\end{array}$ \\
\hline $\begin{array}{l}\text { Maumee AOC } \\
\text { Maumee River } \\
\text { Ottawa River } \\
\text { Turtle Creek } \\
\text { Wolf Creek } \\
\text { Otter Creek } \\
\text { Toussaint River }\end{array}$ & $\begin{array}{l}09 / 17 / 2012 \\
09 / 20 / 2012 \\
09 / 25 / 2012 \\
09 / 28 / 2012 \\
05 / 15 / 2013 \\
10 / 04 / 2012\end{array}$ & $\begin{array}{l}45 \\
40 \\
40 \\
15 \\
40 \\
40\end{array}$ & $\begin{array}{l}3.1 \pm 0.5 \\
6.1 \pm 0.3 \\
5.8 \pm 0.3 \\
2.7 \pm 0.3 \\
3.6 \pm 0.2 \\
5.8 \pm 0.3\end{array}$ & $\begin{array}{l}292.8 \pm 4.7 \\
307.9 \pm 4.2 \\
313.5 \pm 6.3 \\
264.8 \pm 5.3 \\
301.2 \pm 4.3 \\
321.3 \pm 4.8\end{array}$ \\
\hline $\begin{array}{l}\text { Rochester Embayment } \\
\text { Genesee River } \\
\text { Irondequoint Bay } \\
\text { Long Pond }\end{array}$ & $\begin{array}{l}05 / 11 / 2011 \\
04 / 25 / 2012 \\
04 / 26 / 2012\end{array}$ & $\begin{array}{l}20 \\
20 \\
20\end{array}$ & $\begin{array}{l}7.5 \pm 0.6 \\
8.0 \pm 0.6 \\
7.5 \pm 0.3\end{array}$ & $\begin{array}{l}313.9 \pm 7.1 \\
306.2 \pm 5.6 \\
315.7 \pm 7.0\end{array}$ \\
\hline $\begin{array}{l}\text { Niagara River } \\
\text { Middle - Grand Island } \\
\text { Middle - Love Canal } \\
\text { Upper - developed } \\
\text { Upper - undeveloped } \\
\text { Lower }\end{array}$ & $\begin{array}{l}06 / 14 / 2011 \\
06 / 21 / 2011 \\
06 / 12 / 2012 \\
06 / 13 / 2012 \\
07 / 23 / 2013\end{array}$ & $\begin{array}{l}26 \\
24 \\
25 \\
25 \\
50\end{array}$ & $\begin{array}{l}6.2 \pm 0.3 \\
6.5 \pm 0.3 \\
6.8 \pm 0.3 \\
6.8 \pm 0.2 \\
4.2 \pm 0.3\end{array}$ & $\begin{array}{l}284.6 \pm 6.5 \\
312.3 \pm 2.8 \\
334.9 \pm 5.4 \\
317.1 \pm 5.1 \\
290.0 \pm 6.9\end{array}$ \\
\hline $\begin{array}{l}\text { Detroit River } \\
\text { Trenton Channel }\end{array}$ & $\begin{array}{l}05 / 18 / 2011 \\
05 / 09 / 2012\end{array}$ & $\begin{array}{l}20 \\
20\end{array}$ & $\begin{array}{l}5.6 \pm 0.3 \\
6.5 \pm 0.5\end{array}$ & $\begin{array}{l}295.2 \pm 5.1 \\
306.3 \pm 6.9\end{array}$ \\
\hline Ashtabula River & $\begin{array}{l}04 / 25 / 2011 \\
10 / 04 / 2011\end{array}$ & $\begin{array}{l}20 \\
19\end{array}$ & $\begin{array}{l}7.7 \pm 0.4 \\
6.7 \pm 0.5\end{array}$ & $\begin{array}{l}340.4 \pm 6.5 \\
310.7 \pm 8.3\end{array}$ \\
\hline Presque Isle Bay & $05 / 07 / 2013$ & 50 & $5.4 \pm 0.3$ & $325.9 \pm 4.4$ \\
\hline Conneaut Creek & $\begin{array}{r}\mathrm{Re} \\
04 / 26 / 2011 \\
10 / 05 / 2011 \\
05 / 06 / 2013\end{array}$ & $\begin{array}{c}\text { rence Sites } \\
20 \\
20 \\
40\end{array}$ & $\begin{array}{l}7.0 \pm 0.5 \\
6.7 \pm 0.3 \\
4.9 \pm 0.3\end{array}$ & $\begin{array}{l}348.7 \pm 5.1 \\
335.6 \pm 5.3 \\
320.3 \pm 6.6\end{array}$ \\
\hline Huron River & $05 / 09 / 2013$ & 28 & $4.8 \pm 0.3$ & $310.3 \pm 5.6$ \\
\hline Long Point Inner Bay & $04 / 30 / 2013$ & 50 & $5.8 \pm 0.2$ & $267.5 \pm 1.8$ \\
\hline
\end{tabular}


did include age-2 individuals. No age-2 brown bullhead were observed with either skin or liver tumors. A third consideration is the possibility of seasonal effects. The majority of studies relating to brown bullhead tumors have been conducted in the spring and early summer (Blazer and others, 2009a,b). In the present study collections occurred in the spring/early summer (April through June) at some sites and in the late summer/fall (August through October) at some sites (table 1). At one of the reference sites, Conneaut Creek, brown bullhead were collected in both spring and fall. Although only 20 fish were analyzed in each season, the results suggest there were no significant differences between the seasons at this site. However, it is currently unknown if prevalence of either skin or liver tumors will be significantly influenced by the time of year or season the collections occur. A final consideration is that at a number of sites, although raised lip, body surface, or barbel lesions were documented, tissues were not collected for histology, and hence microscopic verification was not possible.

\section{Visible External Lesions}

Visible external lesions included reddened or eroded areas, generally due to inflammation, congestion, or hemorrhage of unknown cause. Hyperpigmented melanistic areas (fig. 2A) were black, non-raised areas noted on the body surface. Barbel abnormalities included shortened, missing, deformed (forked, bent) and the presence of raised areas (fig. 2B). A variety of raised orocutaneous lesions were noted on lip (fig. 2C) and body surface lesions (fig. 2D-F).

The percentage of fish exhibiting visible lip, body surface, and barbel lesions varied among sites (table 2). Additionally, the types of orocutaneous lesions varied among sites. For instance, melanistic areas were not noted in brown bullhead from the Black and Toussaint Rivers; Euclid, Wolf and Otter Creeks; or Long Point Inner Bay. Raised barbel lesions were not noted in the Black and Cuyahoga rivers or most of the sites within the Maumee AOC. No raised lesions were noted on bullheads collected in Wolf or Otter Creeks (table 2).

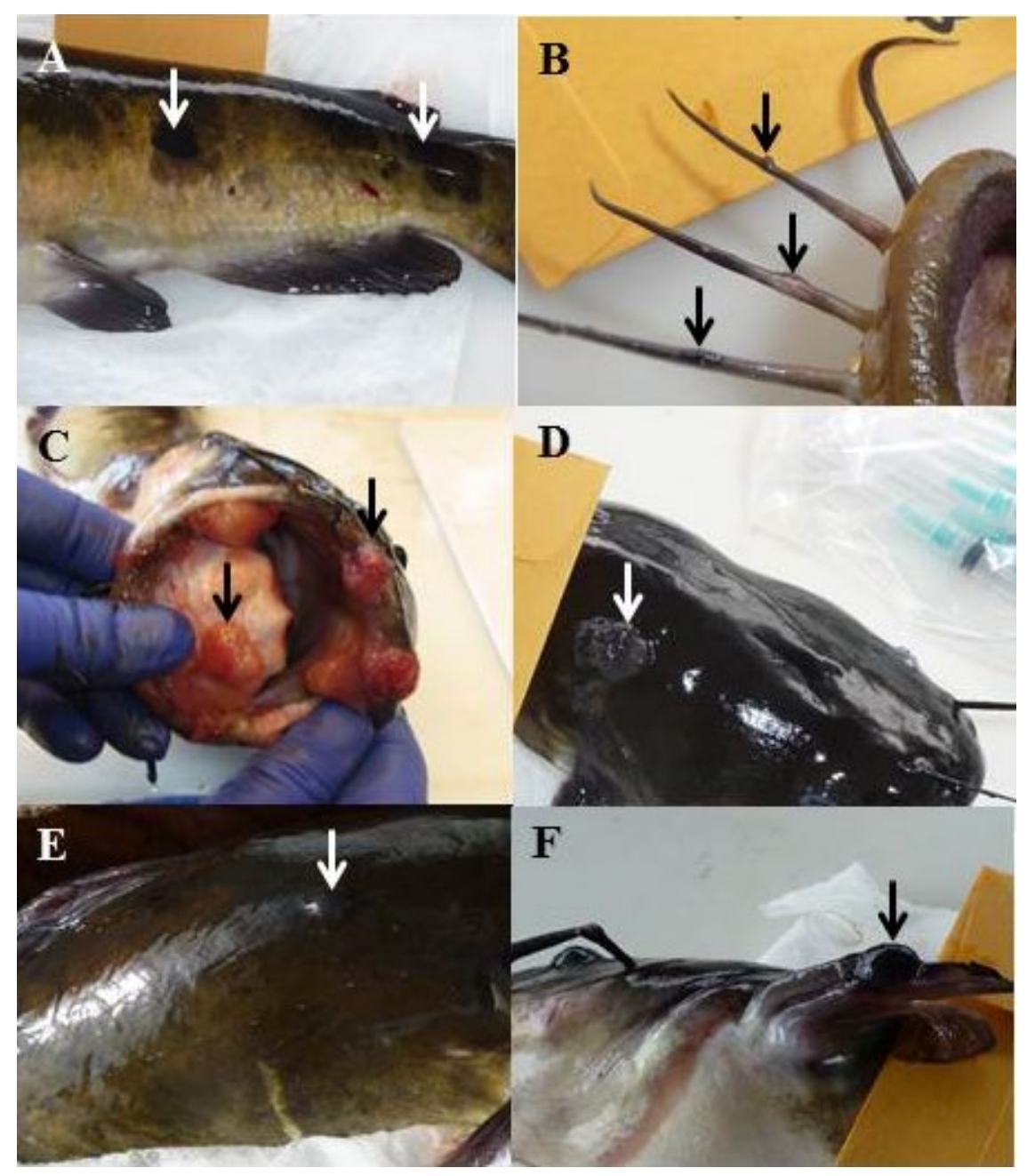

Figure 2. Grossly visible lesions on the external surfaces of brown bullhead: $A$, melanistic areas (arrows) on the lateral surface, $B$, raised areas (arrows) on the barbels, $C$, raised areas (arrows) on the lips and mouth, $D$, pale raised area (arrow) on the body surface, $E$, small raised area (arrow) on the body surface, and $F$, raised black lesion (arrow) on the fin. 
Table 2. Percentage of brown bullhead with lip, body surface, and barbel abnormalities.

\begin{tabular}{|c|c|c|c|c|c|}
\hline \multirow{2}{*}{ Areas of Concern } & \multicolumn{3}{|c|}{ Lip/body surface lesions } & \multicolumn{2}{|c|}{ Barbel abnormalities } \\
\hline & Red/eroded & Melanistic & Raised & Raised & Other ${ }^{1}$ \\
\hline \multicolumn{6}{|l|}{ Black River } \\
\hline Upper Black & 15.0 & 0 & 17.5 & 0 & 27.5 \\
\hline Lower Black & 40.0 & 0 & 10.0 & 0 & 23.3 \\
\hline \multicolumn{6}{|l|}{ Cuyahoga River } \\
\hline New Channel & 4.2 & 4.2 & 8.3 & 0 & 33.3 \\
\hline Old Channel & 0 & 3.7 & 14.8 & 0 & 33.3 \\
\hline Euclid Creek & 0 & 0 & 15.0 & 10.0 & 35.0 \\
\hline \multicolumn{6}{|l|}{ Maumee } \\
\hline Maumee River & 4.4 & 0 & 3.2 & 0 & 11.1 \\
\hline Ottawa River & 2.5 & 7.5 & 10.0 & 2.5 & 55.0 \\
\hline Turtle Creek & 5.0 & 7.5 & 2.5 & 0 & 17.5 \\
\hline Wolf Creek & 13.3 & 0 & 0 & 0 & 0 \\
\hline Otter Creek & 0 & 0 & 0 & 0 & 10.0 \\
\hline Toussaint River & 5.0 & 0 & 10.0 & 2.5 & 12.5 \\
\hline \multicolumn{6}{|l|}{ Rochester Embayment } \\
\hline Genesee River & 10.0 & 45.0 & 30.0 & 20.0 & 40.0 \\
\hline Irondequoint Bay & 0 & 20.0 & 20.0 & 20.0 & 25.0 \\
\hline Long Pond & 5.0 & 5.0 & 20.0 & 30.0 & 40.0 \\
\hline \multicolumn{6}{|l|}{ Niagara River } \\
\hline Middle - Grand Island & 69.2 & 26.9 & 23.1 & 30.8 & 15.4 \\
\hline Middle - Love Canal & 8.3 & 20.8 & 29.2 & 33.3 & 41.7 \\
\hline Upper - developed & 4.0 & 16.0 & 24.0 & 24.0 & 48.0 \\
\hline Upper - undeveloped & 16.0 & 16.0 & 28.0 & 24.0 & 32.0 \\
\hline Lower River & 28.0 & 10.0 & 16.0 & 12.0 & 16.0 \\
\hline \multicolumn{6}{|l|}{ Detroit River } \\
\hline 2011 and 2012 combined & 12.5 & 30.0 & 35.0 & 30.0 & 30.0 \\
\hline \multicolumn{6}{|l|}{ Ashtabula River } \\
\hline spring 2011 & 0 & 20.0 & 30.0 & 10.0 & 35.0 \\
\hline fall 2011 & 0 & 32.0 & 16.0 & 11.0 & 0 \\
\hline combined & 0 & 26.0 & 23.0 & 10.5 & 17.5 \\
\hline Presque Isle Bay & 6.0 & 10.0 & 16.0 & 10.0 & 12.0 \\
\hline \multicolumn{6}{|c|}{ Reference Sites } \\
\hline Conneaut Creek & & & & & \\
\hline spring 2011 & 15.0 & 5.0 & 10.0 & 5.0 & 10.0 \\
\hline fall 2011 & 15.0 & 5.0 & 10.0 & 10.0 & 30.0 \\
\hline spring 2013 & 10.0 & 0 & 7.5 & 0 & 12.5 \\
\hline combined & 12.5 & 2.5 & 8.8 & 3.8 & 15.0 \\
\hline Huron River & 3.6 & 3.6 & 3.6 & 3.6 & 10.7 \\
\hline Long Point Inner Bay & 8.0 & 0 & 2.0 & 8.0 & 4.0 \\
\hline
\end{tabular}

${ }^{1}$ Other barbel abnormalities include missing, shortened, and deformed. 


\section{Microscopic Lesions}

The microscopic proliferative lesions of brown bullhead skin and liver have been described previously by Blazer and others $(2006,2007)$. Melanistic areas on body surface, lips, and fins were noted on fish from a number of sites. The reference sites, as well as sites within the Black River AOC, Cuyahoga River AOC, Maumee AOC, and Presque Isle Bay all had no to few fish ( $10 \%$ or less) with melanistic areas. Conversely, the Rochester Embayment AOC, specifically the Genesee River and Irondequoint Bay, Detroit River AOC, Ashtabula River AOC, and the middle zone of the Niagara River AOC all had greater than $20 \%$ of the brown bullhead exhibiting melanistic areas. In normal brown bullhead skin, the melanin-containing cells are present in the dermis (fig. 3A). In the melanistic or hyperpigmented areas, the melanin-containing cells often appear to have proliferated and migrated from the dermis to the epidermis (fig. 3B). The dermal melanin-containing cells are small, generally somewhat elongated cells, densely packed with melanin (fig. 3A). The melanin-containing cells within the melanistic areas are often pleomorphic and melanosomes less densely packed. These areas are hyperpigmented areas within the epidermis and do not have the histologic appearance of melanomas (Okihiro and others, 1993; Gimenez-Conti and others, 2001). Raised black lesions were observed and in most cases these were papillomas with increased pigment in the epidermis. Only one melanoma was observed in the current study, and this was on a barbel. In this case the proliferating melanocytes extended into the underlying connective tissue and muscle. It is unknown if these hyperpigmented areas could be preneoplastic lesions.

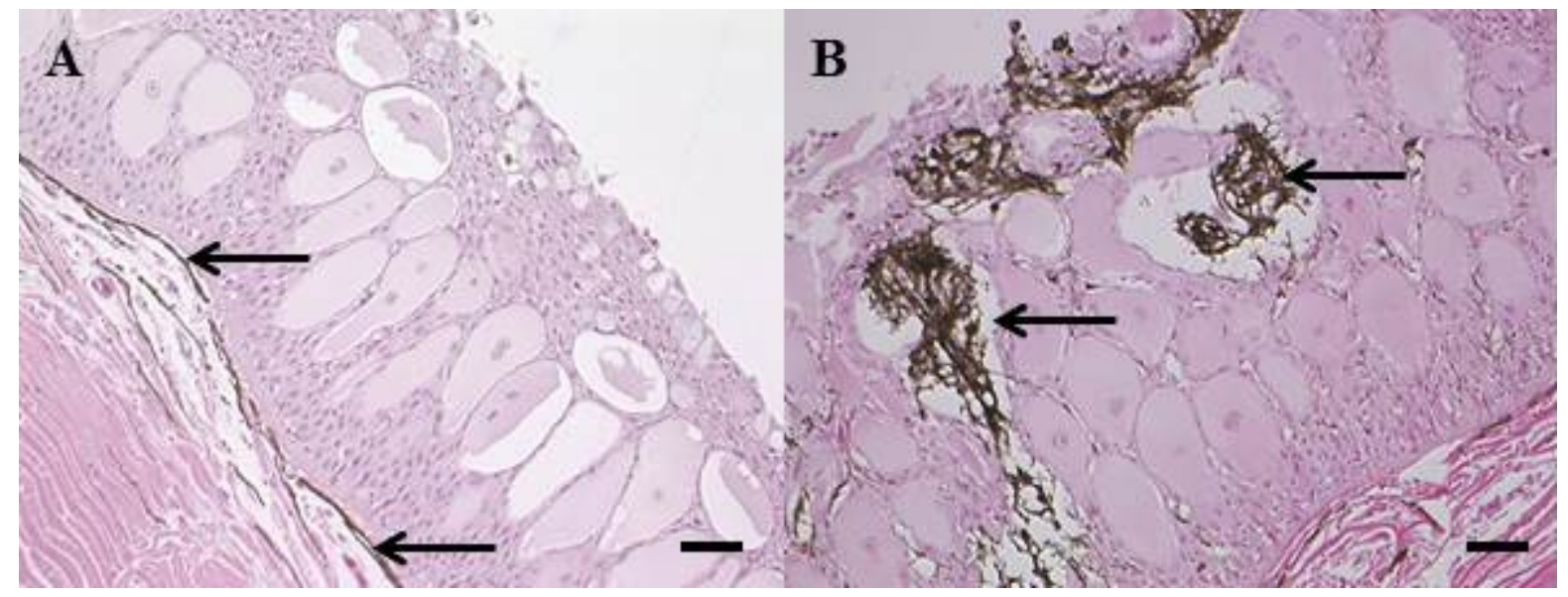

Figure 3. Microscopic appearance of $A$, normal and $B$, melanistic areas of skin observed on the body surface of brown bullhead. In normal skin, melanocytes (black arrows) are present in the dermis. In sections of melanistic skin, numerous abnormal melanocytes (black arrows) are observed in the epidermis (scale bars equal 50 micrometers [ $\mu \mathrm{m}]$ ).

Raised lesions including both raised reddened areas as well as the rough-appearing papillomatous lesions or smooth raised lesions of lips, body surface, and barbels were examined microscopically. Neoplastic lesions of the lips, fins, body surface, and barbels (fig. 4) included papilloma (benign, noninvasive epithelial neoplasm), squamous cell carcinoma (malignant, invasive epithelial neoplasm), melanoma (a malignant neoplasm of melanocytes), osteoma (benign neoplasm of bone) and osteosarcoma (malignant neoplasm of bone).

Non-neoplastic, proliferative hepatic lesions included foci of cellular alteration and bile duct proliferation. Eosinophilic, basophilic, and vacuolated foci of cellular alteration were documented. Foci of cellular alteration are areas in which the cells stain differentially, but are not encapsulated or invasive (fig. 5A). Altered foci, particularly basophilic foci, have been postulated to be preneoplastic in some fish species (Hendricks and others, 1984; Hinton and others, 1988; Boorman and others, 1997). While it is not known which altered foci, if any, are preneoplastic in brown bullhead, there is evidence the foci are indicators of contaminant exposure (Baumann and Okihiro, 2000; Blazer and others, 2006; 2009 b). Neoplastic lesions include hepatocellular adenoma (benign or noninvasive hepatic neoplasm), which are generally encapsulated and cause compression of surrounding tissue (fig. 5B). Hepatocellular carcinoma (malignant or invasive hepatic neoplasm) were also noted and generally consisted of multifocal areas of neoplastic hepatocytes invading normal tissue.

Bile duct hyperplasia was the most commonly observed nonneoplastic proliferative response. As in other fish species (Boorman and others, 1997; Wolf and Wolfe, 2005), the differentiation between bile duct hyperplasia and bile duct neoplasia in bullheads may be difficult. Bile duct proliferation consisted of a focal or multifocal increase in bile duct profiles which were well-differentiated and did not cause compression of surrounding tissue or expand into adjacent hepatic parenchyma (fig. 5C). Cholangioma, a benign or noninvasive bile duct neoplasm, consisting of proliferating bile ducts with abnormal morphology and arrangement as well as cholangiocarcinoma, a malignant or invasive bile duct neoplasm (fig. 5D), were observed. 


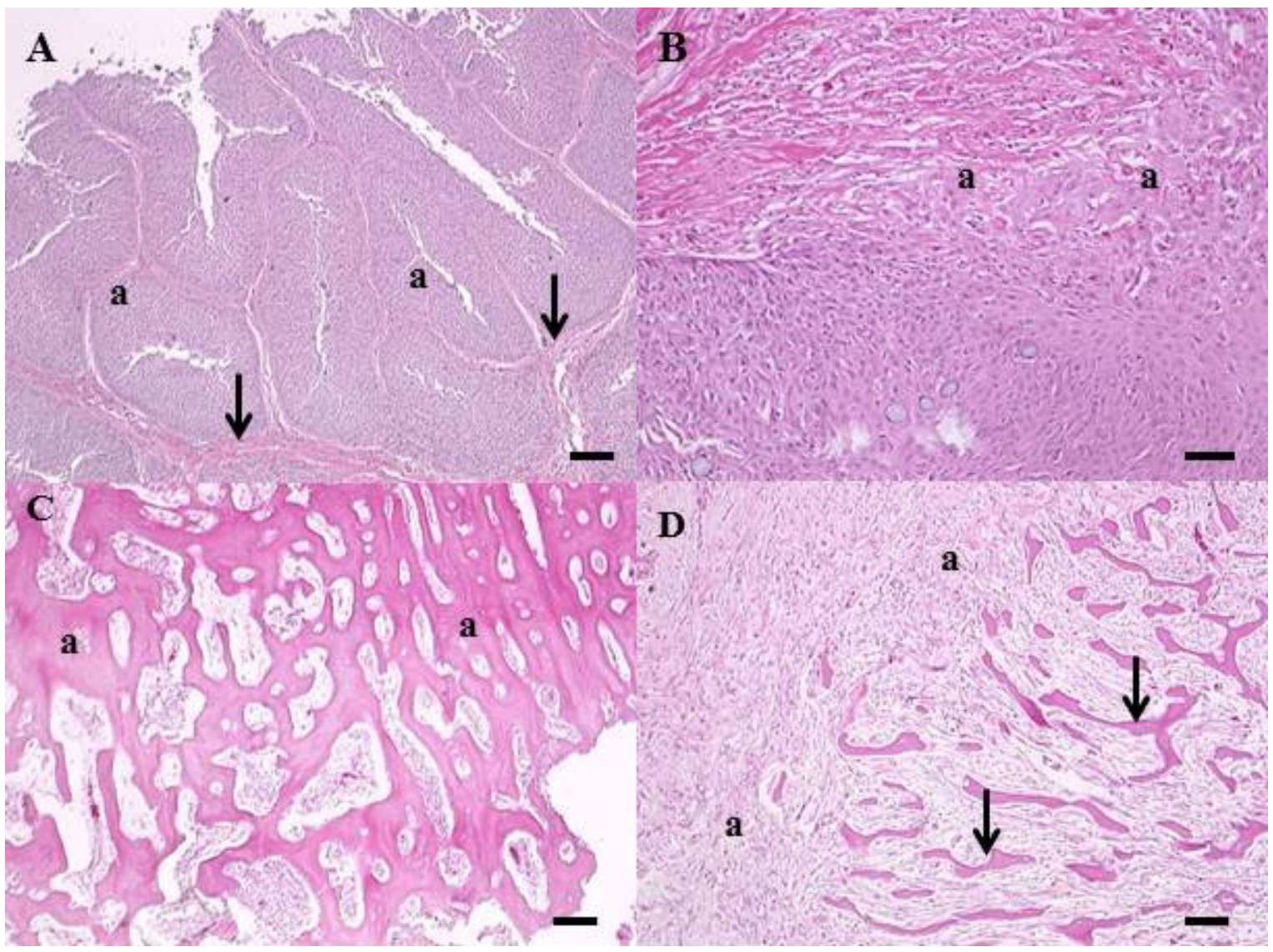

Figure 4. Microscopic appearance of raised lesions observed on brown bullhead: $A$, papilloma characterized by papillary folds of proliferating epithelial cells (a) that do not penetrate through the basement membrane (arrows), scale bar equals $100 \mu \mathrm{m}, B$, section of a squamous cell carcinoma of the body surface with neoplastic epithelial cells (a) invading through the basement membrane into the underlying dermis, scale bar equals $50 \mu \mathrm{m}, C$, section of an osteoma with anastosmosing irregular trabeculae of proliferating bone (a), scale bar equals $100 \mu \mathrm{m}, D$, osteosarcoma characterized by thin trabeculae of neoplastic bone (arrows) within a matrix of fibrous tissue (a), scale bar equals $100 \mu \mathrm{m}$. 


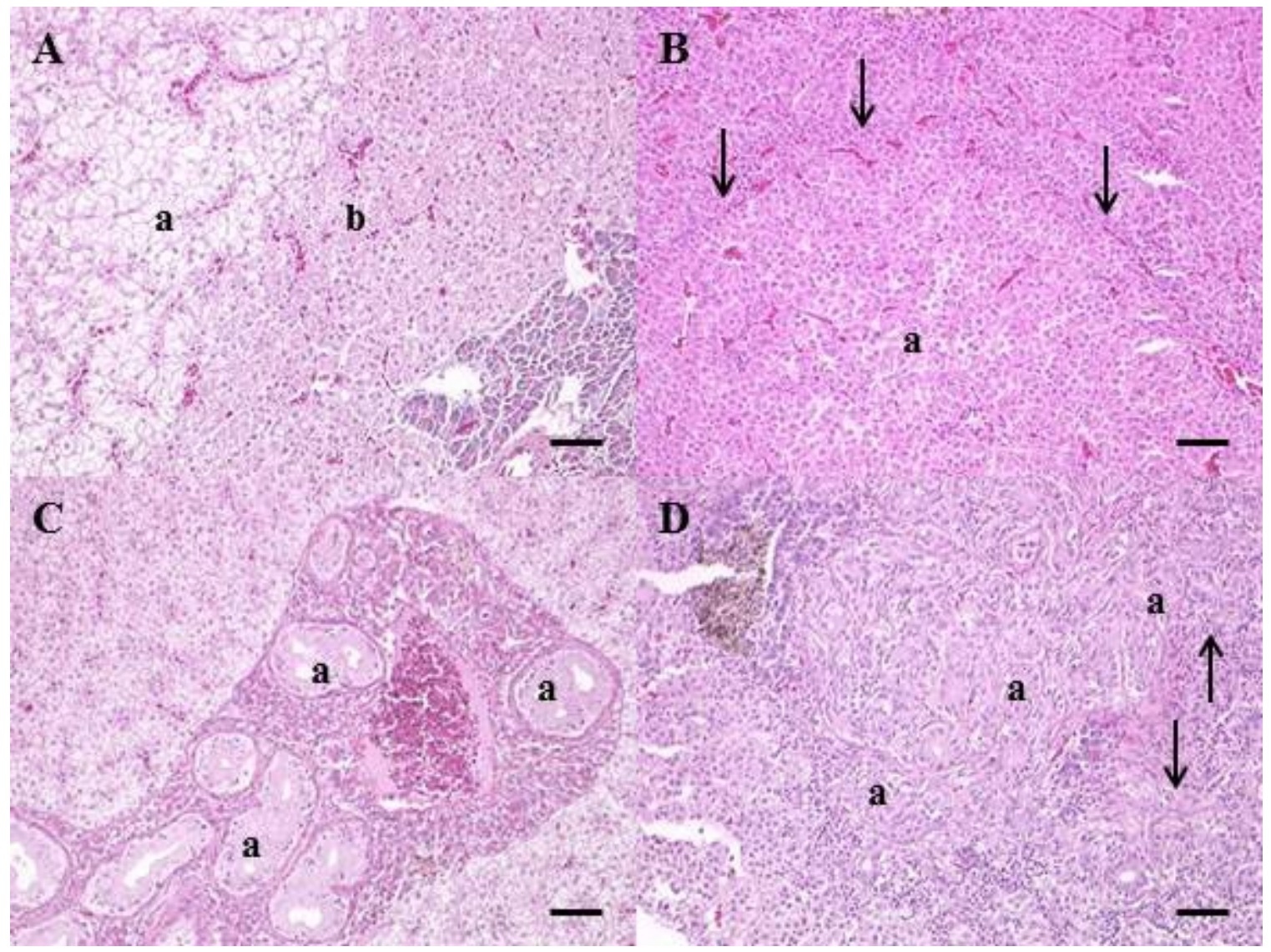

Figure 5. Microscopic appearance of proliferative liver lesions: $A$, vacuolated cell focus (a) comprised of hepatocytes with large clear cytoplasmic vacuoles and no distinct border separating it from surrounding hepatocytes (b), $B$, hepatic adenoma (a) causing compression (arrows) of surrounding tissue, $C$, bile duct hyperplasia is characterized by increased profiles of normal bile ducts (a), often in multiple areas throughout the tissue and $D$, cholangiocarcinoma comprised of bile ducts (a) abnormal in size and morphology and invading into the surrounding tissue (arrow). Scale bars equal $50 \mu \mathrm{m}$. 
Table 3. Percentage of brown bullhead with external and liver neoplasms and putative preneoplastic liver lesions.

\begin{tabular}{|c|c|c|c|}
\hline Area of concern & $\begin{array}{c}\text { External } \\
\text { neoplasms }\end{array}$ & $\begin{array}{c}\text { Liver } \\
\text { neoplasms }\end{array}$ & $\begin{array}{c}\text { Foci of } \\
\text { cellular } \\
\text { alteration }\end{array}$ \\
\hline $\begin{array}{l}\text { Black River } \\
\text { Upper Black } \\
\text { Lower Black }\end{array}$ & $\begin{array}{l}15.0 \\
10.0\end{array}$ & $\begin{array}{l}12.5 \\
10.0\end{array}$ & $\begin{array}{l}7.5 \\
3.3\end{array}$ \\
\hline $\begin{array}{l}\text { Cuyahoga River } \\
\text { New Channel } \\
\text { Old Channel } \\
\text { Euclid Creek }\end{array}$ & $\begin{array}{r}4.2 \\
14.8 \\
12.5\end{array}$ & $\begin{array}{r}8.3 \\
3.7 \\
12.5\end{array}$ & $\begin{array}{l}25.0 \\
14.8 \\
17.5\end{array}$ \\
\hline $\begin{array}{l}\text { Maumee } \\
\text { Maumee River } \\
\text { Ottawa River } \\
\text { Turtle Creek } \\
\text { Wolf Creek } \\
\text { Otter Creek } \\
\text { Toussaint River }\end{array}$ & $\begin{array}{l}2.2 \\
10.0 \\
2.5 \\
0 \\
0 \\
2.5\end{array}$ & $\begin{array}{c}4.4 \\
17.5 \\
17.5 \\
0 \\
17.1 \\
17.5\end{array}$ & $\begin{array}{r}6.6 \\
27.5 \\
15.0 \\
13.3 \\
17.1 \\
5.0\end{array}$ \\
\hline $\begin{array}{l}\text { Rochester Embayment } \\
\text { Genesee River } \\
\text { Irondequoint Bay } \\
\text { Long Pond }\end{array}$ & $\begin{array}{l}30.0 \\
35.0 \\
30.0\end{array}$ & $\begin{array}{r}10.0 \\
5.0 \\
10.0\end{array}$ & $\begin{array}{l}20.0 \\
10.0 \\
25.0\end{array}$ \\
\hline $\begin{array}{l}\text { Niagara River } \\
\text { Middle-Grand Island } \\
\text { Middle-Love Canal } \\
\text { Upper-developed } \\
\text { Upper-undeveloped } \\
\text { Lower River }\end{array}$ & $\begin{array}{l}61.5 \\
45.8 \\
28.0 \\
44.0 \\
22.0\end{array}$ & $\begin{array}{l}7.7 \\
4.2 \\
4.0 \\
4.0 \\
0\end{array}$ & $\begin{array}{r}7.7 \\
4.2 \\
4.0 \\
8.0 \\
14.0\end{array}$ \\
\hline $\begin{array}{l}\text { Detroit River } \\
\text { Trenton Channel }\end{array}$ & 32.5 & 7.5 & 5.0 \\
\hline Ashtabula River & 30.0 & 7.5 & 10.0 \\
\hline Presque Isle Bay & 12.0 & 4.0 & 14.0 \\
\hline \multicolumn{4}{|c|}{ Reference Sites } \\
\hline Conneaut Creek & 10.0 & 2.5 & 8.8 \\
\hline Huron River & 3.6 & 7.2 & 3.6 \\
\hline Long Point Inner Bay & 6.0 & 4.0 & 6.0 \\
\hline
\end{tabular}




\section{Site Comparisons}

For site comparisons the percentage of fish with microscopically verified skin and liver neoplasms, as well as foci of cel-

lular alteration, was calculated (table 3). There is no basin wide agreement on what constitutes an impairment in terms of the fish tumor BUI. The recommendation of the expert panel was that putative preneoplastic changes such as foci of cellular alteration be documented, but only neoplastic lesions should be considered in calculating prevalences (Blazer and others, 2009b). However, neither the definition nor the prevalence of tumors to be accepted for delisting purposes is consistent and varies among states and AOCs. The Ohio EPA currently considers the fish tumor BUI as impaired if DELTs (deformities, eroded fins, lesions, tumors) or brown bullhead liver tumor incidence levels exceed regional target values or values found in either Lake Erie fish populations and are due to contaminant sources from within the boundaries of the AOC. The BUI will be considered restored when DELT values do not exceed 3\% in lacustuary and boat sites or 1.3\% in wading sites and brown bullhead liver tumor prevalence rate (i.e. neoplastic and preneoplastic liver tumors) does not exceed 5\% (Ohio Environmental Protection Agency, 2014). Baumann and others (1996) suggested a skin tumor prevalence of greater than $25 \%$ and a liver neoplasm prevalence greater than $5 \%$ in brown bullhead or white sucker should be interpreted as an indicator of environmental degradation. The Lake Erie Lakewide Management Plan indicates an AOC is impaired when the incidence of intestinal or liver tumor prevalence equals or exceeds $5-7 \%$ and external tumors equal or exceed $13-15 \%$ in samples of 30 fish or more which are $250 \mathrm{~mm}$ or greater and when the DELT index is greater than $0.5 \%$ (Baumann and others, 2000).

\section{Reference Sites}

Three reference sites (Huron River, Conneaut Creek, and Long Point Inner Bay) were evaluated; however, the target sample size (30 or greater) was not achieved at the Huron site. Twenty-eight brown bullhead were collected, and all were age- 3 or older. Two fish (7.2\%) were observed with raised lesions of the lips or barbels. The lip lesion was a papilloma; no tissue was collected from the raised barbel lesion. Two of the brown bullhead (7.2\%) had liver neoplasms, both of which were bile duct tumors.

A total of 80 bullhead were collected from Conneaut Creek during two seasons and 2 years, and all except one was age- 3 or older. Raised lesions were noted on $9(11.3 \%)$ of the fish and 8 of these were neoplastic lesions, including papilloma, melanoma, osteoma, and osteosarcoma. No tissue was collected from the other individual. Two of the brown bullhead (2.5\%) from this site had liver neoplasms, one of hepatocellular and one of biliary origin.

Fifty bullhead were collected from Long Point Inner Bay, and all were age-3 or older. Five (10\%) of the brown bullhead had raised lesions on lips or barbels, and three (6.0\%) were papillomas. Two brown bullhead (4.0\%) had bile duct tumors.

\section{Presque Isle Bay}

The fish tumor BUI was delisted at Presque Isle in 2013. Fifty brown bullhead were collected at this site, and all but two were age-3 or older. Twelve (24\%) had raised lesions on lips, body surface, or barbels. Six (12\%) of these were verified as skin neoplasms, all papillomas. Tissues were not collected for four of the brown bullhead with raised lesions. Two fish (4\%) had liver neoplasms, one had a bile duct tumor, and one had both bile duct and hepatocellular tumors.

\section{Black River AOC}

Brown bullhead were collected in the upper (40) and lower (30) reaches of the Black River. No melanistic areas or raised lesions on barbels were noted at either site. Seven fish (17.5\%) had raised lesions on the lips or body surface. Unfortunately, tissue was not collected from three of these lesions. The remaining four, as well as two of the raised reddened lesions $(15 \%)$, were neoplastic lesions, including papillomas and two squamous cell carcinomas. Liver neoplasms, both hepatocellular and bile duct, were noted in five (12.5\%) fish.

The lower Black River site had three fish (10\%) with raised lip lesions and $12(40 \%)$ with red raised or eroded body surface lesions. Tissue was collected from only one of the raised lip lesions, and it was diagnosed as a squamous cell carcinoma. Two of the body surface lesions were papillomas for a total of $10 \%$ verified skin tumors. Three fish (10\%) had liver tumors, all of bile duct origin. 


\section{Cuyahoga River AOC}

Bullhead were collected at three areas within the Cuyahoga River AOC - the new channel, the old channel, and Euclid Creek. Only 27 fish were collected in the old channel, and four of these were age-2. No raised barbel lesions were noted; however, four (14.8\%) lip or body surface lesions were observed. All of these were verified as neoplastic and included a papilloma, squamous cell carcinomas, and osteosarcomas. Only one fish from this site had a liver tumor, and it was of bile duct origin.

Twenty-four brown bullhead were collected from the new channel site and three of these were age-2. Raised lip lesions were observed on two (8.3\%) of the fish; unfortunately, only one (4.2\%) was collected for microscopic verification.

Forty brown bullhead were collected at Euclid Creek, and all of these were age- 3 or older. Raised lesions on lips and barbels were observed on eight (20\%) of the fish. Tissue was not collected from three of these fish; the remaining five (12.5\%) were all neoplasms, including papillomas and a squamous cell carcinoma. Five brown bullhead from this site also had liver neoplasms, all with bile duct tumors and one with both a cholangiocarcinoma and a hepatocellular tumor.

\section{Maumee River AOC}

Brown bullhead were collected at six sites within the Maumee AOC with sample sizes of 40 or more at all but Wolf Creek. Melanistic areas were only observed at Ottawa River and Turtle Creek. No raised lesions were observed at Wolf Creek or Otter Creek. In general, the prevalence of raised lesions of the lips, body surface, and barbels was low. The prevalence of microscopically verified skin neoplasms was less than $10 \%$ at all sites. However, no tissues were collected from two fish with raised lesions at the Ottawa River, one at Turtle Creek, and three at the Toussaint River. Squamous cell carcinomas were observed in fish from the Maumee and Ottawa Rivers.

No liver neoplasms were observed at Wolf Creek; however, eight of the 15 fish collected were age-2. The Maumee River also had a low prevalence (4.4\%) of liver neoplasms (one hepatocellular, one bile duct), but 12 of the 45 fish were age-2. The liver neoplasm prevalence at the Ottawa River, Turtle Creek, Otter Creek, and Toussaint River was 17.1 to 17.5\%. These sites also had a lower number of age-2 fish. All the observed liver tumors from the Touisaant River were of bile duct origin. All fish exhibiting liver tumors from the Ottawa River and Turtle Creek had bile duct tumors; however, at each site one fish had both bile duct and hepatocellular neoplasia. Otter Creek brown bullheads exhibited both hepatocellular and bile duct tumors.

\section{Rochester Embayment AOC}

Only 20 brown bullhead were collected at each of the three sites within the Rochester Embayment AOC. At all sites within this AOC, the brown bullheads collected, except one year-4, were 5 years of age or older. In the Genesee River sample, eight $(40 \%)$ had raised lesions on lips, fins, or barbels. Six $(30 \%)$ of these were neoplasms and included papillomas and one squamous cell carcinoma. A high percentage (45\%) of these fish exhibited melanistic areas. Two fish (10\%) had liver neoplasms, one with both hepatocellular and biliary tumors. At Long Pond eight brown bullheads (20\%) had raised lesions on lips, body surface, or barbels and six of these (30\%) were neoplasms, all papillomas. Two fish had liver neoplasms, both of bile duct origin. At Irondequint Bay, eight brown bullhead had raised lip, body surface, fin, or barbel lesions, seven (35\%) of which were neoplasms that included papillomas, squamous cell carcinomas, and osteoma. Only one fish (5\%) had a bile duct tumor.

\section{Niagara River AOC}

Fifty brown bullhead were collected in each of three zones of the river-upper, middle, and lower. In addition, the upper and middle zones were each further divided into two sites. The results for each of the five sites are presented separately in tables 2 and 3. Here we combined sites and present results by zone. Brown bullhead collected in the upper zone were all age-3 or older. Twenty-two (44\%) had raised lesions of the lips, body surface, or barbels, all of which were papillomas or osteomas. Two fish (4\%) had liver neoplasms both of which were bile duct tumors.

All 50 fish collected in the middle zone were year-4 or older. Twenty five (50\%) had raised lesions on the lips, body surface, fins, or barbels. Twenty-seven brown bullhead (54\%), some with red or eroded lesions, had microscopically verified skin neoplasms that included papillomas, squamous cell carcinomas, and osteomas. Only three of the brown bullhead (6\%) from this zone had liver neoplasms that included hepatocellular and bile duct tumors.

The brown bullhead collected in the lower zone were somewhat younger than those from the other two zones, and seven were age-2. Thirteen (26\%) had raised lesions of the lips, body surface, fins, or barbels, and $11(22 \%)$ of these were neoplasms, all papillomas. Two fish had both papillomas and osteomas. There were no liver tumors noted at this site. 


\section{Detroit River AOC}

A total of 40 brown bullhead were collected in the Trenton Channel area in spring 2011 and 2012, all age-3 or older. Grossly observable lesions included raised lesions on lip/body surface and barbels, as well as melanistic areas. Twenty-three (57.5\%) had raised lesions on lips, body surface, or barbels. Eleven (27.5\%) were neoplastic skin lesions, including papillomas, squamous cell carcinomas, and osteomas. No hepatocellular neoplasia was observed, and three fish (7.5\%) had bile duct tumors.

\section{Ashtabula River AOC}

A total of 40 brown bullhead were collected from the Ashtabula River during two seasons in 2011, ranging in age from 3 to 13 years. Skin tumors were noted on $30 \%$ of the fish collected and included papilloma, squamous cell carcinoma, and osteoma. Neoplastic liver lesions, observed in $7.5 \%$ of the brown bullhead, included cholangioma and hepatocellular adenoma.

\section{Summary and Conclusions}

A variety of external and liver tumors were observed in brown bullhead from sites within all of the AOCs monitored. The Conneaut Creek and Long Point Inner Bay reference sites had liver tumor prevalences of $4.0 \%$ or less and external tumor prevalences of $10.0 \%$ or less. Certain areas within some of the AOCs had similar low prevalences. At some AOCs (Rochester Embayment, Niagara River, Detroit, Ashtabula) the prevalence of external neoplasms was higher than that of liver neoplasms, while at others (Maumee) a higher prevalence of liver neoplasms occurred. The risk factors associated with individual neoplasms may differ. External (orocutaneous) tissues are in constant contact with the water and sediment, while exposure of liver tissue requires absorption and often metabolism of chemical contaminants. Additionally, individual tissues may accumulate chemicals differentially. In order to effectively remediate and restore healthy fish populations, the causes and associated risk factors (chemical and biological) of the various tumors observed need to be understood. Ideally, further studies would be directed toward identifying these risk factors.

\section{References Cited}

Arcand-Hoy, L.D., and Metcalfe, C.D., 1999, Biomarkers of exposure of brown bullhead (Ameiurus nebulosus) to contaminants in the lower Great Lakes, North America: Environmental Toxicology and Chemistry v. 18, p. 740-749.

Baumann, P.C., 1992, The use of tumors in wild populations of fish to assess ecosystem health: Journal of Aquatic Ecosystem Stress and Recovery, v.1, p. 35-46.

Baumann, P., Cairns, V., Kurey, B., Lambert, L., Smith, I., Thoma, R., 2000, Fish tumors and other deformities. Lake Erie Lakewide Management Plan Technical Report No. 6, accessed April 7, 2014, at http://www.epa.gov/lakeerie/buia/lamp6.pdf.

Baumann, P.C., and Harshbarger, J.C., 1998, Long term trends in liver neoplasm epizootics of brown bullhead in the Black River, Ohio: Environmental Monitoring and Assessment, v. 53, p. 213-223.

Baumann, P.C., Harshbarger, J.C., Hartman, K.J., 1990, Relationship between liver tumors and age in brown bullhead populations from two Lake Erie tributaries: Science of the Total Environment, v. 94, p. 71-87.

Baumann, P.C., and Okihiro, M.S., 2000, Cancer, in Ostrander, G.K, ed., The laboratory fish: San Diego, Ca., Academic Press, Inc., p. 591-616.

Baumann, P.C., Smith, I.R., and Metcalfe, C.D., 1996, Linkages between chemical contaminants and tumors in benthic Great Lakes fish: Journal of Great Lakes Research, v. 22, p. 131-152.

Blair, B.D., Crago, J.P., Hedman, C.J., and Klaper, R.D., 2013, Pharmaceuticals and personal care products found in the Great Lakes above concentrations of environmental concern: Chemosphere, v. 93, p. 2116-2123.

Blazer, V.S., Fournie, J.W., Wolf, J.C., Wolfe, M.J., 2006, Diagnostic criteria for proliferative liver lesions in the Brown Bullhead (Ameiurus nebulosus): Diseases of Aquatic Organisms, v. 72, p. 19-30. 
Blazer, V.S., Fournie, J.W., Wolf, J.C., Wolfe, M.J., 2007, Manual for the microscopic diagnosis of proliferative liver and skin lesions in the brown bullhead (Ameiurus nebulosus), accessed Febuary 5, 2014, at http://seagrant.psu.edu/publications/ technicaldocs/histofieldmanual.pdf

Blazer, V.S., Rafferty, S.D., Baumman, P.C., Smith, S.B., and Obert, E.C., 2009a, Assessment of the "tumors or other deformities" beneficial use impairment in brown bullhead: I. Orocutaneous tumors: Journal of Great Lakes Research, v. 35, p. 517-526.

Blazer, V.S., Rafferty, S.D., Baumman, P.C., Smith, S.B., and Obert, E.C., 2009b, Assessment of the "tumors and other deformities" beneficial use impairment in brown bullhead: II. Liver tumors: Journal of Great Lakes Research, v. 35, p. 527-537.

Boorman, G.A., Botts, S., Bunton, T.E., Fournie, J.W., Harshbarger, J.C., Hawkins, W.E., Hinton, D.E., Jokinen, M.P., Okihiro, M.S. and Wolfe, M.J., 1997, Diagnostic criteria for degenerative, inflammatory, proliferative nonneoplastic and neoplastic liver lesions in Medaka (Oryzias latipes): consensus of a national toxicology program pathology working group: Toxicologic Pathology, v. 25, p. 202-210.

Gimenez-Conti, I., Woodhead, A.D., Harshbarger, J.C., Kazianis, S., Setlow, R.B., Nairn, R.S., and Walter, R.B., 2001, A proposed classification scheme for Xiphophorus melanomas based on histopathologic analyses: Marine Biotechnology, v. 3 (Supplement 1), p. S100-106.

Hayes M.A., Smith, I.R., Rushmore, T.H., Crane, T.L., Thorn, C., Kocal, T.E., Ferguson, H.W., 1990, Pathogenesis of skin and liver neoplasms in white suckers from industrially polluted areas in Lake Ontario: Science of the Total Environment, v. 94, p. $105-123$.

Hendricks, J.D., Meyers, T.R., and Shelton, D.W., 1984, Histological progression of hepatic neoplasia in rainbow trout (Salmo gairdneri): Narional Cancer Institute Monograph, v. 63, p. 321-326.

Hinton, D.E., Couch, J.A., Teh, S.J., and Courtney, L.A., 1988, Cytological changes during progression of neoplasia in selected fish species: Aquatic Toxicology, v. 11, p. 77-112.

Hirethota, P.S., 1992, Use of natural populations of brown bullhead (Ameiurus nebulosus Lesueur) as ecosystem health indicators of contaminant-related stress: State University of New York, Dissertation, 185 p.

International Joint Commission, 1991, Commission approves list/delist criteria for Great Lakes Areas of Concern: Focus on International Joint Commission Activities, v. 16, p. 1-5, accessed October 30, 2013, at http://www.ijc.org/php/publications/ html/listdelist/index.html.

International Joint Commission, 2009, Great Lakes Chemical of Emerging Concern Advisory workgroup: Great Lakes Water Quality Agreement Priorities 2007-2009 series, Special Publication 2009-01, Winsor, Ontario, Canada, accessed October 30, 2013, at http://www.ijc.org/en/priorities/2009/chemical.

Iwanowicz, L.R., Blazer, V.S., Hitt, N.P., McCormick, S.D., DeVault, D. and Ottinger, C.A., 2012, Histologic, immunologic and endocrine biomarkers indicate contaminant effects in fishes of the Ashtabula River: Ecotoxicology, v. 21, p.165-182.

Klaper, R., and Welch, L.C., 2011, Emerging contaminant threats and the Great Lakes: Existing science, existing science, estimating relative risk and determining policy: Alliance for the Great Lakes, accessed December 14, 2013, at http://www. greatlakes.org/Document.Doc?id=1072.

Klečka, G., Persoon, C., and Currie, R., 2010, Chemicals of emerging concern in the Great Lakes Basin: An analysis of environmental exposures: Reviews of Environmental Contamination and Toxicology, v. 207, p. 1-93.

Knapton, R.W., and Petrie, S.A., 1999, Changes in distribution and abundance of submerged macrophytes in the Inner Bay at Long Point, Lake Erie; implications for foraging waterfowl: Journal of Great Lakes Research, v. 25, p. 783-798.

Koch, J.D., and Quist, M.C., 2007, A technique for preparing fin rays and spines for age and growth analysis: North American Journal of Fisheries Management, v. 27, p. 782-784.

Leadley, T.A., Balch, G., Metcalfe, C.D., Lazar, R., Mazak, E., Habowsky, J., and Haffner, G.D., 1998, Chemical accumulation and toxicological stress in three brown bullhead (Ameiurus nebulosus) populations of the Detroit River, Michigan, USA: Environmental Toxicology and Chemistry, v. 17, p. 1756-1766. 
Luna, L.G., 1992, Histopathologic Methods and Color Atlas of Special Stains and Tissue Artifacts: Gaithersburg, Md., American Histolabs Inc., 767 p.

Maccubbin, A.E., and Ersing, N., 1991, Tumors in fish from the Detroit River: Hydrobiologia, v. 219, p. 1756-1766.

Ohio Environmental Protection Agency, 2005, Huron River watershed TMDL program fact sheet: State of Ohio Environmental Protection Agency, Division of Surface Water, 3 p, accessed March 10, 2014, at http://www.epa.state.oh.us/portals/35/tmdl/ Huron_Final_Factsheet_080905.pdf.

Ohio Environmental Protection Agency, 2014, Delisting guidance and restoration targets for Ohio areas of concern: Columbus, Ohio, State of Ohio Environmental Protection Agency, Division of Surface Water, 90 p.

Okihiro, M.S., Whipple, J.A., Groff, J.M., and Hinton, D.E., 1993, Chromatophoromas and chromatophore hyperplasia in Pacific rockfish (Sebastes spp.): Cancer Research, v. 53, p.1761-1769.

Pinkney, A.E., Harshbarger, J.C., May, E.B., and Reichert, W.L., 2004, Tumor prevalence and biomarkers of exposure and response in brown bullhead (Ameiurus nebulosus) from the Anacostia River, Washington, D.C. and Tuckahoe River, Maryland, USA: Environmental Toxicology and Chemistry, v. 23, p. 638-647.

Premdas, P.D., Metcalfe, T.L., Bailey, M.E., and Metcalfe, C.D., 1995. The prevalence and histological appearance of lip papillomas in white sucker (Catostomus commersoni) from two sites in central Ontario, Canada: Journal of Great Lakes Research, v. 21, p. $207-218$.

Rafferty S.D., Blazer, V.S., Pinkney, A.E., Grazio, J.L., Obert, E.C., and Boughton, L., 2009, A historic perspective on the "fish tumors or other deformities" beneficial use impairment at Great Lakes Areas of Concern: Journal of Great Lake Research, v. 35 , p. $496-506$.

Rafferty, S.D., and Grazio, J.L., 2006, Field manual for assessing internal and external anomalies in brown bullhead (Ameiurus nebulosus), accessed December 5, 2013, at http://seagrant.psu.edu/publications/technical docs/bullheadfieldmanual.pdf.

Smith, S.B., Blouin, M.A., and Mac, M.J., 1994, Ecological comparisons of Lake Erie tributaries with elevated incidence of fish tumor: Journal of Great Lakes Research, v. 20, p. 701-716.

Smith, S.B., Donahue, A., Lipkin, R., Blazer, V.S., Schmitt, C.J., and Goede, R.W., 2002, Illustrated field guide for assessing external and internal anomalies in fish: Federal Series: Information and Technology Report 2002-0007, 56 p.

Smith, I.R., Ferguson, H.W., and Hayes, M.A., 1989, Histopathology and prevalence of epidermal papillomas epidemic in brown bullhead, Ictalurus nebulosus (Lesueur) and white sucker, Catostomus commersoni (Lacepede), populations from Ontario, Canada: Journal of Fish Diseases, v. 12, p. 373-388.

Wolf, J.C., and Wolfe, M.J., 2005, A brief overview of nonneoplastic hepatic toxicity in fish: Toxicological Pathology, v. 33, p. $75-85$.

\section{Appendix 1. Morphometric Data, Visible and Microscopic Abnormalities.}

Available online at http://dx.doi.org/10.3133/ofr20141105. 

Prepared by the West Trenton Publishing Service Center

For more information, contact:

Leetown Science Center

U.S. Geological Survey

11649 Leetown Road

Kearneysville, WV 25430

http://www./sc.usgs.gov/ 


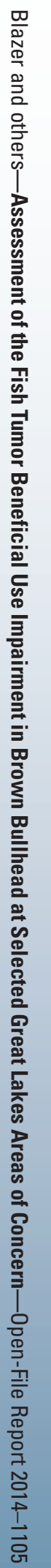

